The Bangladesh Veterinarian (2009) 26(2) : $54-60$

\title{
Prevalence and risk factors of mastitis in dairy cows
}

\author{
M. A. Rahman ${ }^{1}$, M. M. U. Bhuiyan*, M. M. Kamal ${ }^{1}$ and M. Shamsuddin \\ Department of Surgery and Obstetrics, Faculty of Veterinary Science, Bangladesh \\ Agricultural University, Mymensingh-2202, Bangladesh
}

\begin{abstract}
Identification of risk factors is important for the design of control programmes for mastitis in cows. Information about farms and management was collected at a farm visit. California Mastitis Test (CMT) was performed to assess sub-clinical mastitis, and cows, udder and milk were examined for clinical mastitis. A total of 347 lactating cows from 83 farms in the dry season (November - February) and 388 lactating cows from 89 farms in the wet season (June - October) were studied. The overall prevalence of mastitis was $19.9 \%$ and $44.8 \%$ in dry and wet seasons, respectively. The prevalence of mild mastitis was $17.3 \%$ and $40.7 \%$, whereas that of moderate mastitis was $2.6 \%$ and $4.1 \%$ in dry and wet seasons, respectively. The prevalence of mastitis was higher $(\mathrm{P}<0.01)$ in wet than in dry season. On average, $18.7 \%$ quarters had mastitis during the wet season and $6.9 \%$ in the dry season. In the dry and wet seasons, respectively, $63.9 \%$ and $11.2 \%$ had completely dry floors, and the prevalence of mastitis was $22.6 \%$ and $30.0 \%$. On the other hand, $88.8 \%$ and $36.1 \%$ of 83 farms had partly or completely wet and soiled floor and the prevalence of mastitis was $40.0 \%$ and $59.5 \%$ in the dry and wet seasons, respectively. Udder cleanliness, milk yield and peri-parturient diseases significantly $(\mathrm{P}<0.01)$ increased the risk of mastitis. The prevalence of mastitis is regarded as quite high. Dry and clean floor to keep cow's udder and teat clean would help control mastitis in the dairy farms of Bangladesh. (Bangl. vet. 2009. Vol. 26, No. 2, 54-60)
\end{abstract}

\section{Introduction}

Mastitis is one of the most devastating diseases in the dairy industry. Economic consequences of mastitis, clinical or sub-clinical, include reduced milk yield, poorer quality milk, increased culling rate and increased cost of veterinary services and medicine. Dairy farmers in Bangladesh are not always aware of the best practices to control mastitis (Rahman et al., 1997). Besides bacterial infection, there are many risk factors associated with mastitis. The disease cannot be eradicated but can be reduced to low levels by good management.

Several studies on mastitis include morphology of udder and teats and milk yield (Ahmed et al., 2005), dry cow therapy (Hossain, 2004) and the prevalence of sub-clinical mastitis (Quaderi, 2005). No precise and comprehensive reports are available, and a study to identify the risk factors related to mastitis is necessary. Clinical mastitis can be diagnosed by signs, but CMT has a special importance for the diagnosis of sub-clinical mastitis. Therefore, this study utilized CMT and cow and

\footnotetext{
1 Department of Livestock Services, Dhaka, Bangladesh

*Correspondence: E-mail:- mmubhuiyan@gmail.com
} 
udder scoring protocols to determine the prevalence of mastitis and the possible risk factors during dry and wet seasons.

\section{Materials and Methods}

The study was undertaken from September 2004 to July 2005. The field investigations were carried out at dairy farms of the Bangladesh Milk Producer's Cooperative Union Ltd. (Milk-Vita), covering the Districts of Sirajganj and Pabna.

\section{Selection of dairy herd and animals}

A total of 83 farms in the dry season and 89 farms in the wet season were randomly selected from Pabna and Sirajganj Districts. In total, 347 lactating cows in the dry season (November - February) and 388 lactating cows in the wet season (June - October) of different ages, parities and lactation stages were examined. The cows were crossbred between indigenous Zebu and Friesian, Sahiwal or Jersey. The cows were housed loose, or tied up at night and tethered during the day. In the dry season, legume and other green forages were available, and after morning milking cows grazed till $1400 \mathrm{~h}$. During the wet season, cows were housed 24 hours a day, when the grazing lands were submerged under flood-water. Then milling byproducts and rice straw were fed. Dry cows were fed with rice straw, green grass (when available) and minimum amount of milling by-products. Cows were handmilked twice daily; however, during the last part of lactation, many farmers milked their cows once daily. All the farms had natural ventilation in tin shed housing. A few farms had poor drainage. Farmers did not clean floor and udder with disinfectants. Cattle were bathed infrequently using tap water. Generally, mastitis was treated with systemic antibiotics.

\section{Farm survey and data collection}

The farms were surveyed twice in a year, once between November 2004 and February 2005 representing the dry season, and between June and October 2005 representing the wet season. The farmers were interviewed to collect information on production system. Udders and milk were examined to identify clinical mastitis. Udder and CMT scores were recorded according to the procedure of National Mastitis Council (1999). Briefly, findings of udder palpation were scored into 1, 2, 3 and 4 for no swelling or pain in udder, swollen ventral quarter, generalized swollen quarter and, swollen and painful udder, respectively. CMT scores were 1 (mixture remains liquid, homogeneous, no coagulation or gel formation) 2 (a coagulation of milk begins, but there is no tendency toward a gel formation; in some cases, this coagulation may disappear after prolonged rotation of the paddle), 3 (mixture coagulates, does not stick and distinctly forms a gel) and 4 (mixture coagulates and sticks, tends to form jelly; swirling the cup moves mixture towards the center exposing the outer edges of the cup) for negative, weak positive, distinct positive and strong positive, respectively. Positive cases of mastitis were expressed as mild (udder score 1-2, CMT score 2-4) or moderate (udder score 3, CMT score 2-4) on the basis of udder and CMT scores. Milk was examined by CMT for sub-clinical mastitis. 


\section{Statistical analysis}

The information gathered in the questionnaires was entered in the Microsoft Excel worksheet. The data were organized to generate other variables including age, days in milk, herd size and floor space per cow. The prevalence of mastitis was calculated as the percentage of mastitis affected cows out of the total lactating cows. Binary logistic regression was performed giving the mastitis diagnosis score as response variable and the potential risk factors in the regression model for inferential analyses. At first, to see the effect of individual risk factors on mastitis, binary logistic regression analysis was performed giving the single factors in the model. In this stage, factors that showed $\mathrm{P}<0.01$ were included in the multi-factor regression model. In the multiple regression models, factors those showed $\mathrm{P}<0.01$ were removed and further analysis were performed to find out the significant effect of risk factors on the prevalence of mastitis. The effects were considered significant when the probability level showed below $5 \%$. All the descriptive and inferential analyses were performed in Minitab ${ }^{\circledR}$ statistical software for windows (Anon, 2000).

\section{Results and Discussion}

A total of 347 cows in dry season and 388 cows in wet season were studied, and the overall prevalence of mastitis was $19.9 \%$ and $44.8 \%$ (Table 1), respectively. The prevalence of mild mastitis was $17.3 \%$ and $40.7 \%$ and moderate mastitis was $2.6 \%$ and $4.1 \%$ in dry and wet seasons, respectively. The overall prevalence of mastitis and of mild mastitis was significantly $(\mathrm{P}<0.01)$ higher in wet than in dry season.

Table 1. Percentages of mastitic cows in different seasons

\begin{tabular}{l|c|c|c|c|c}
\hline Seasons & $\begin{array}{c}\text { Number of } \\
\text { cows examined }\end{array}$ & $\begin{array}{c}\text { CMT positive } \\
\text { cases }\end{array}$ & $\begin{array}{c}\text { Mild mastitis } \\
\%\end{array}$ & $\begin{array}{c}\text { Moderate } \\
\text { mastitis \% }\end{array}$ & $\begin{array}{c}\text { Overall \% } \\
\text { of mastitis }\end{array}$ \\
\hline Dry & 347 & 69 & $17.3^{\mathrm{b}}$ & 2.6 & $19.9^{\mathrm{b}}$ \\
Wet & 388 & 174 & $40.7^{\mathrm{a}}$ & 4.1 & $44.8^{\mathrm{a}}$ \\
\hline
\end{tabular}

a, $b$ Values in the same column with different superscripts differ significantly $(\mathrm{P}<0.01)$

In dry season, 6.8\% (95/1388) quarters and in wet season, $18.7 \%(290 / 1548)$ quarters were affected with mastitis (Table 2). Mild mastitis was in 5.8\% quarters during the dry season and in $16.6 \%$ during the wet season (Table 2). Moderate mastitis affected $1.0 \%$ and $2.1 \%$ in dry and wet seasons, respectively. The percentage of quarters with mastitis differed significantly $(\mathrm{P}<0.001)$ between seasons (Table 2$)$.

The majority of the dairy farms had 1-5 lactating cows (Table 3). In the dry season there was considerable variation in the prevalence of mastitis depending on the farm size (15.9 to $100 \%$ ). However, such differences did not exist during the wet season (40 to $46.4 \%$; Table 3). Nevertheless, the effect of season and herd size on the prevalence of mastitis was not significant. 
Table 2. Percentage of quarters affected with mastitis

\begin{tabular}{l|c|c|c|c|c|c|c}
\hline Seasons & \multirow{2}{*}{$\begin{array}{c}\text { Number of } \\
\text { quarters }\end{array}$} & $\begin{array}{c}\text { Number of } \\
\text { examined }\end{array}$ & \multirow{2}{*}{$\begin{array}{c}\% \text { of } \\
\text { quarters } \\
\text { affected }\end{array}$} & $\begin{array}{c}\text { quarters } \\
\text { affected }\end{array}$ & \multicolumn{2}{|c|}{$\begin{array}{c}\text { Quarters affected by } \\
\text { mild mastitis }\end{array}$} & \multicolumn{2}{|c|}{$\begin{array}{c}\text { Quarters affected by } \\
\text { moderate mastitis }\end{array}$} \\
\cline { 5 - 8 } & & & & Number & $\%$ & Number & $\%$ \\
\hline Dry & 1388 & 95 & $6.8^{\mathrm{b}}$ & 81 & $5.8^{\mathrm{b}}$ & 14 & 1.0 \\
Wet & 1548 & 290 & $18.7^{\mathrm{a}}$ & 257 & $16.6^{\mathrm{a}}$ & 33 & 2.1 \\
\hline
\end{tabular}

$\mathrm{a}, \mathrm{b}$ The value in the same column with different superscripts differed significantly $(\mathrm{P}<0.01)$

Table 3. Percentages of farms with mastitis

\begin{tabular}{l|c|c|c|c}
\hline \multirow{2}{*}{ Variables } & \multicolumn{2}{|c|}{ Dry season } & \multicolumn{2}{c}{ Wet season } \\
\cline { 2 - 5 } & $\begin{array}{c}\text { Farms } \\
\text { studied } \\
(\mathrm{n}=83)\end{array}$ & $\begin{array}{c}\text { \% of farms } \\
\text { with } \\
\text { mastitis }\end{array}$ & $\begin{array}{c}\text { Farms } \\
\text { studied } \\
(\mathrm{n}=89)\end{array}$ & $\begin{array}{c}\% \text { of farms } \\
\text { with } \\
\text { mastitis }\end{array}$ \\
\hline Herd size : & 69 & 15.9 & 71 & 46.4 \\
1 to 5 cows & 10 & 60.0 & 13 & 46.2 \\
6 to 10 cows & 4 & 100.0 & 5 & 40.0 \\
11 to 34 cows & & & & \\
\hline Floor component : & 73 & $30.0^{\mathrm{a}}$ & 82 & $58.5^{\mathrm{a}}$ \\
$\quad$ Separate brick-block floor & 10 & $20.0^{\mathrm{b}}$ & 7 & $28.6^{\mathrm{b}}$ \\
$\quad$ Soil floor & & & & \\
\hline Floor condition : & 53 & $22.6^{\mathrm{b}}$ & 10 & $30.0^{\mathrm{b}}$ \\
$\quad$ Completely dry & 30 & $40.0^{\mathrm{a}}$ & 79 & $59.5^{\mathrm{a}}$ \\
$\quad$ Partly or completely wet and soiled & 30
\end{tabular}

$\mathrm{a}, \mathrm{b}$ Values in the same column with different superscripts differed significantly $(\mathrm{P}<0.05)$

* Separate brick-block floor means floor made by placing brick-blocks together without plastering on it

The prevalence of mastitis was $30.6 \%$ and $58.5 \%$ in farms with brick-block floor and $20.0 \%$ and $28.6 \%$ in farms with soil floor during the dry and wet seasons, respectively. Irrespective of season, the prevalence of mastitis varied significantly between separate brick-block floor and soil floor $(\mathrm{P}<0.05$; Table 3$)$. The floor was completely dry in 53 farms $(63.9 \%)$ during the dry season and in only 10 farms $(11.2 \%)$ during the wet season. Only $22.6 \%$ farms were affected with mastitis when the floor was completely dry; however, the percentage of farm with mastitis was $59.5 \%$ when the farm floor was wet and soiled. The prevalence of mastitis was significantly affected by floor conditions (completely dry vs. partly or completely wet and soiled floor; $\mathrm{P}<0.05$; Table 3 ). This can be explained by the fact that farms with soil floor would dry more quickly than the brick floor (Hogan et al., 1990). It appeared that the floor was a potential source for mastitis organisms to enter the udder through the teat orifice. Kivaria et al. (2004) showed scarcity of water as one of the potential risk factors for the prevalence of mastitis. This is true for the area where the present investigator worked. In the present study, during the wet season, water 
was plenty, and in most cases, except the barn and household, land was submerged by flood-water. The cows remained on the floor all day and got dirty. The floor was muddy, and drainage was difficult to maintain. In addition, the warm temperature and high humidity favoured the growth of organisms (Fox et al., 1995).

The prevalence of mastitis with respect to age, lactation, breed and pregnancy of cows in two seasons are shown in Table 4 . The prevalence of mastitis increased with age in dry and wet seasons $(\mathrm{P}<0.05$; Table 4$)$. The number of lactations had a significant effect on the prevalence of mastitis irrespective of seasons $(\mathrm{P}<0.05$, Table 4). The prevalence of mastitis was the lowest in first lactation $(12.3$ to $31.6 \%)$ in both seasons and the highest in $6^{\text {th }}$ to $13^{\text {th }}$ lactation $(41.3 \%)$ in dry season and $5^{\text {th }}$ lactation $(65 \%)$ in wet season. The majority of the cows examined were crossbred between Holstein-Friesian and Zebu (72 to $77 \%$ ). The breed did not show a significant effect on the prevalence of mastitis. Moreover, pregnancy had no influence on the prevalence of mastitis (Table 4).

Table 4. Prevalence of mastitis and age, parity and breed

\begin{tabular}{|c|c|c|c|c|}
\hline \multirow[t]{2}{*}{ Variable } & \multicolumn{2}{|c|}{ Dry season } & \multicolumn{2}{|c|}{ Wet season } \\
\hline & $\begin{array}{c}\text { Cows } \\
\text { studied } \\
(\mathrm{n}=347)\end{array}$ & $\begin{array}{c}\% \text { of cows } \\
\text { with mastitis }\end{array}$ & $\begin{array}{c}\text { Cows } \\
\text { studied } \\
(\mathrm{n}=388)\end{array}$ & $\begin{array}{c}\% \text { of cows } \\
\text { with mastitis }\end{array}$ \\
\hline \multicolumn{5}{|l|}{ Age : } \\
\hline 3 to 6 years & 193 & $12.4^{\mathrm{a}}$ & 102 & $35.3^{a}$ \\
\hline 7 to 8 years & 115 & $27.0^{\mathrm{b}}$ & 152 & $40.1^{\mathrm{a}}$ \\
\hline 9 to 19 years & 39 & $35.9^{\mathrm{b}}$ & 134 & $57.5^{\mathrm{b}}$ \\
\hline \multicolumn{5}{|l|}{ Lactation: } \\
\hline $1^{\text {st }}$ & 65 & $12.3^{\mathrm{a}}$ & 57 & $31.6^{\mathrm{a}}$ \\
\hline $2^{\text {nd }}$ & 103 & $11.7^{\mathrm{a}}$ & 90 & $35.6^{\mathrm{a}}$ \\
\hline $3^{\text {rd }}$ & 83 & $25.3^{\mathrm{ab}}$ & 103 & $41.7^{\mathrm{ab}}$ \\
\hline $4^{\text {th }}$ & 44 & $22.7 \mathrm{ab}$ & 52 & $55.7^{b}$ \\
\hline $5^{\text {th }}$ & 23 & $26.1^{\mathrm{ab}}$ & 40 & $65.0^{\mathrm{b}}$ \\
\hline $6^{\text {th }}-13^{\text {th }}$ & 29 & $41.3^{\mathrm{b}}$ & 46 & $50.7^{b}$ \\
\hline \multicolumn{5}{|l|}{ Breeds : } \\
\hline Friesian cross & 250 & 16.0 & 297 & 47.1 \\
\hline Sahiwal cross & 53 & 35.8 & 22 & 31.8 \\
\hline Jersey cross & 02 & 100.0 & 14 & 35.4 \\
\hline Local Zebu & 42 & 19.5 & 55 & 32.7 \\
\hline \multicolumn{5}{|l|}{ Reproductive state : } \\
\hline Pregnant and lactating & 185 & 17.8 & 215 & 40.0 \\
\hline Non-pregnant and lactating & 162 & 22.2 & 173 & 44.8 \\
\hline
\end{tabular}


Regarding age and parity, several studies were in agreement with the present findings of increased mastitis in advancing age and parity (Slettbakk et al., 1995; Radostits et al., 2000; Quaderi, 2005). It has been shown that high-yielding and aged cows are more prone to mastitis. In the high-yielding cows the glandular tissues are more susceptible to infection (Slettbakk et al., 1995; Radostits et al., 2000). Similarly, the defence mechanism in aged cows is poorer than in younger cows (Dulin et al., 1988). Polymorphonuclear leukocyte function is more active in primiparous than multiparous cows (Dulin et al., 1988). Interestingly, high parity cows are more productive, and it is likely that cows with advancing age and parity are prone to mastitis.

Cows without a history of periparturient disease had a prevalence of $39.4 \%$ mastitis; in contrast, $86.7 \%$ of cows with a history of periparturient disease had mastitis (Table 5). Such data were available only during the wet season. The lower immunity level of periparturient cows makes the cow more prone to infection in the udder (Rainard and Riollet, 2006). Once a cow gets infected or diseased during the periparturient period, it becomes more susceptible to udder infection due to lowered immunity (Nickerson, 1994; Peeler et al., 1994). Calcium ions are necessary for muscle constriction. As a result, in milk fever, low level of calcium decreases the rigidity of the teat sphincter that perhaps allows the organism to pass into the udder (Paape and Guidry, 1993). In addition, cows having infected uterine discharge and retained placenta risk the udder and teats being contaminated (Peeler et al., 1994).

Table 5. Percentages of mastitis in cows with periparturient diseases during the wet season

\begin{tabular}{lcc|c}
\hline \multicolumn{1}{c|}{ Variable } & $\begin{array}{c}\text { Number of cows } \\
(\mathrm{n}=388)\end{array}$ & $\begin{array}{c}\text { Mastitis positive } \\
\text { cases }\end{array}$ & \% of mastitis \\
\hline $\begin{array}{l}\text { Cows without a history of } \\
\text { periparturient diseases }\end{array}$ & 343 & 135 & 39.4 \\
$\begin{array}{l}\text { Cows with a history of } \\
\text { periparturient disease }\end{array}$ & 45 & 39 & 86.7 \\
\hline Retained placenta & 21 & 17 & 80.9 \\
Vaginal prolapse & 9 & 9 & 100.0 \\
Uterine prolapse & 8 & 7 & 87.5 \\
Milk fever & 7 & 6 & 85.7 \\
\hline
\end{tabular}

In conclusion, keeping the udder clean, particularly in the wet season, may help reduce the prevalence of mastitis. Suitable floor, regular cleaning of the floor, milkman's cleanliness, regular teat-dipping at milking, treating new clinical cases promptly, identification of sub-clinical mastitis and dry cow therapy may reduce the prevalence of mastitis. 


\section{References}

Ahmed JU, Sutradhar S, Rahman MM 2005: Morphological characteristics of udders and teats in relation to mastitis and milk yield in crossbred dairy cows. The Bangladesh Veterinarian 22 23-28.

Anon 2000: MINITAB ${ }^{\circledR}$. Statistical Software, Release 13 for Windows ${ }^{\circledR}$ inc. 3081, Chapter 9, State College, Pennsylvania 16801, USA pp. 377-383.

Dulin AM, Paape MJ, Nickerson SC 1988: Comparison of phagocytosis and chemiluminescence by blood and mammary gland neutrophils from multiparous and nulliparous cows. American Journal of Veterinary Research 9 172-177.

Fox LK, Chester ST, Hallberg JW, Nickerson SC, Pankey JW, Weaver LD 1995: Survey of intramammary infections in dairy heifers at breeding age and first parturition. Journal of Dairy Science 78 1619-1628.

Hogan JS, Smith KL, Todhunter DA, Schoenberger PS 1990: Bacterial counts associated with recycled chopped newspaper bedding. Journal of Dairy Science 73 1756-1767.

Hossain SMA 2004: Efficacy of dry cow therapy in mastitis control strategy. MS Thesis. Department of Surgery and Obstetrics, Faculty of Veterinary Science, Bangladesh Agricultural University, Mymensingh, Bangladesh.

Kivaria FM, Noordhuizen JPTM, Kapaga AM 2004: Risk factors associated with subclinical mastitis in smallholder dairy cows in Tanzania. Tropical Animal Health and Production 36 581-592.

National Mastitis Council 1999: Laboratory Handbook on Bovine Mastitis. National Mastitis Council, Madison, WI, USA.

Nickerson SC 1994: Bovine mammary gland - structure and function - relationship to milk production and immunity to mastitis. Review of Agricultural Practice 15 8-18.

Paape MJ, Guidry A 1993: The teat defenses of mammary gland. Advances in Experimental Medicine and Biology 225 457-463.

Peeler EJ, Otte MJ, Esslemont RJ 1994: Interrelationship of periparturient diseases in dairy cows. The Veterinary Record 5 129-132.

Quaderi MA 2005: Prevalence of sub-clinical mastitis in dairy farms. MS Thesis, Department of Surgery and Obstetrics, Faculty of Veterinary Science, Bangladesh Agricultural University, Mymensingh, Bangladesh.

Radostits OM, Gay CC, Blood DC, Hinchcliff KW 2000: Mastitis. In: Veterinary Medicine, A Textbook of the Diseases of Cattle, Sheep, Pigs, Goats and Horses. $9^{\text {th }}$ Edn, W B Saunders Co. Philadelphia, USA pp. 603-612.

Rahman MS, Norruddin M, Rahman MM 1997: Prevalence and distribution of mastitis in crossbred and exotic dairy cows. The Bangladesh Veterinarian 14 1-4.

Rainard P, Riollet C 2006: Innate immunity of the bovine mammary gland. Veterinary Research 37 369-400.

Slettbakk T, Jorstad A, Farver TB, Holmes JC 1995: Impact of milking characteristics and morphology of udder and teats on clinical mastitis in first and second lactation in Norwegian cattle. Preventive Veterinary Medicine 24 235-244. 